\title{
Studies on the preparation and crystal polymorphism of 2-acetamidobenzamide and related compounds
}

\author{
Joanne M. Kelleher, Marie T. McAuliffe, Humphrey A. Moynihan,* \\ and Nicholas D. Mullins \\ Department of Chemistry / Analytical and Biological Chemistry Research Facility, University \\ College Cork, College Road, Cork, Republic of Ireland \\ E-mail: h.moynihan@ucc.ie
}

\begin{abstract}
2-Acetamidobenzamide 1 exists in two crystal polymorphic forms: $\alpha$ and $\beta$. The $\alpha$ form features an approximately planar molecular conformation and an intramolecular $\mathrm{N}-\mathrm{H}$...O hydrogen bond. In the $\beta$ form, the amido groups are out of the plane of the benzene ring and no intramolecular hydrogen bonds are present. In our study, the $\alpha$ form was found to be the more readily obtainable initially, usually as well-formed needles. 2-Acetamido-4-chlorobenzamide 8 and 2-acetamido-5chlorobenzamide 9 were prepared and assessed as additives in recrystallizations of 2acetamidobenzamide. In the presence of compound 8, attempted recrystallization of 2acetamidobenzamide gave crystals of the anhydrous form of 2-methylquinazol-4-one 4. Addition of compound 9 had no effect on the crystal form obtained. 10,11-Dihydro-5-acetyldibenzo[b,e][1,4]diazepin-11-one $\mathbf{1 4}$ was prepared as a conformational mimic of the molecular conformation of the $\beta$ form of 2-acetamidobenzamide. Compound $\mathbf{1 4}$ had no effect on the recrystallization of 2-acetamidobenzamide from acetone when added in $10 \% \mathrm{w} / \mathrm{w}$ or from water when added in $1 \% \mathrm{w} / \mathrm{w}$. When 14 was added in $10 \% \mathrm{w} / \mathrm{w}$ quantities to crystallizations of 2acetamidobenzamide from water, fine crystallites were obtained which gave infra-red spectra consistent with the $\alpha$ form, but gave PXRD patterns suggesting the presence of another form or compound. Disruption of the intramolecular hydrogen bonds in the $\alpha$ form of 2acetamidobenzamide 1 by direct trimethylsilylation gave mixtures of 1 and 2-methylquinazol-4one 4. Indirect trimethylsilylation by reaction of 2-methyl-4H-benzo $[d][1,3]$ oxazin-4-one 3 with tris(trimethylsilyl)amine gave crystals of the anhydrous form of 2-methylquinazol-4-one 4. 2Phthalimidobenzoic acid 18 and 2-phthalimidobenzamide 19 were prepared as structural analogues of compound $\mathbf{1}$ which are incapable of possessing an intramolecular hydrogen bond. Addition of compound $\mathbf{1 8}$ to recrystallizations of 2-acetamidobenzamide $\mathbf{1}$ had no effect on the outcome. However addition of compound 19 resulted in needle-like crystals of the $\alpha$ form of considerably reduced dimensions.
\end{abstract}

Keywords: Crystal polymorphism, crystal hydrates, 2-acetamidobenzamide, 2-methylquinazol4-one 


\section{Introduction}

It is now widely appreciated that the occurrence of polymorphism in molecular crystalline solids ${ }^{1}$ impacts on the production of fine chemical products such as pharmaceuticals ${ }^{2}$, pigments ${ }^{3}$ and photographic couplers ${ }^{4}$. 2-Acetamidobenzamide 1 exemplifies many of the issues that can arise in the solid state chemistry of such compounds. Compound $\mathbf{1}$ possesses a molecular structure consisting of an aromatic core bearing polar functionalities. The solid state chemistry of compound 1 features extensive hydrogen-bonding and exhibits crystal polymorphism. Two crystal polymorphs of 2-acetamidobenzamide have been reported ${ }^{5,6}$, designated $\alpha$ (CSD refcode ACBNZA) and $\beta$ (CSD refcode ABCNZA01). The conformations of the 2-acetamidobenzamide molecules differ markedly in the two crystal forms. These conformations can be characterised in terms of the torsional angles, $\tau_{1}$ and $\tau_{2}$, describing the orientation of the amide functionalities relative to the benzene ring. These angles are defined, and the resulting conformations illustrated, in Figure 1. 2-acetamidobenzamide molecules in the $\alpha$ form also posses an intramolecular hydrogen-bond absent in the $\beta$ form.<smiles>CC(=O)Nc1ccccc1C(N)=O</smiles>

1

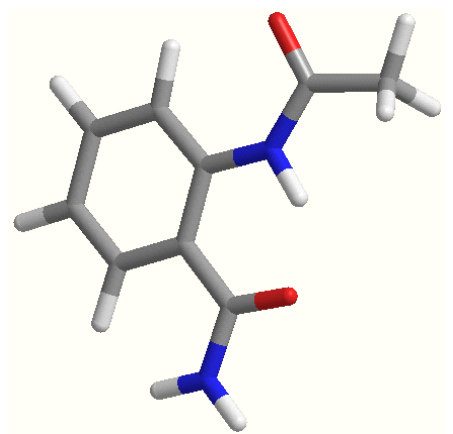

$\alpha$

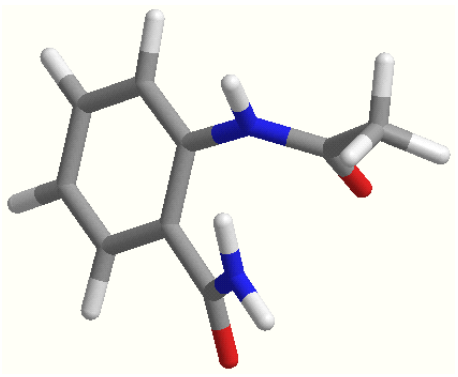

$\beta$

Figure 1. The conformations of 2-acetamidobenzamide 1 in the $\alpha$ and $\beta$ forms. The torsional angles $\tau_{1}$ and $\tau_{2}$ are defined by atoms $\mathrm{O}_{1}-\mathrm{C}_{2}-\mathrm{C}_{3}-\mathrm{C}_{4}$ and $\mathrm{C}_{3}-\mathrm{C}_{4}-\mathrm{N}_{5}-\mathrm{C}_{6}$ respectively, and have values of -28.1 and $169.6^{\circ}$ in the $\alpha$ structure and 131.4 and $60.2^{\circ}$ in the $\beta$ structure $^{5}$. 
Two of the earliest routes to compound 1 were by treatment of anthranilamide 2 with acetic anhydride $^{7}$ and by reaction of 2-methyl-4H-benzo[d][1,3]oxazin-4-one 3 with ammonium hydroxide $^{8}$ (Scheme 1). The crystal polymorphism of 1 was first indicated by differing reported melting points of material obtained from these routes. Subsequent work confirmed the existence of polymorphs of 1 based on differing melting points, IR and powder X-ray diffraction (PXRD) data $^{9}$. However, neither route was found to be polymorph specific. Moreover, although compound 1 can be recrystallized from a wide range of solvents, there is no consensus in the literature on the best choice of solvent and conditions to obtain either form. For example, Errede et al. found that supercooling solutions of acetone or methanol gave fine crystals of the $\alpha$ form and that larger crystals of the $\beta$ form could be grown from acetone, methanol or aqueous solutions ${ }^{5}$; while Barnett et al. found that the $\alpha$ form could be obtained by slow cooling of hot saturated solutions of water, ethanol, methanol or ethyl acetate ${ }^{10}$. Barnett et al. ${ }^{10}$ also found that the $\beta$ form initially proved difficult to obtain, but that once the $\beta$ form had been obtained it was the form that resulted from many crystallization conditions which had previously given the $\alpha$ form. As the $\alpha$ form has a melting point of $179-180^{\circ} \mathrm{C}^{9}$ and a density of $1.325 \mathrm{~g} \mathrm{~cm}^{-35,6}$; while the $\beta$ form has a melting point of $189-190^{\circ} \mathrm{C}^{9}$ and a density of $1.345 \mathrm{~cm}^{-35,6}$, it would be reasonable to conclude that the $\beta$ form is likely to be the thermodynamically preferred form, while there may be a kinetic preference for the $\alpha$ form. When samples of compound $\mathbf{1}$ are heated, an intramolecular condensation can occur to give 2-methylquinazol-4-one $4^{5,9,11}$. Compound 4 itself exists in multiple crystal forms, including a hydrate and an anhydrous form ${ }^{11}$. Solid state complexes of compounds $\mathbf{1}$ and $\mathbf{4}$ have been reported ${ }^{11}$, as well as several solvates of compound $\mathbf{1}^{10}$.
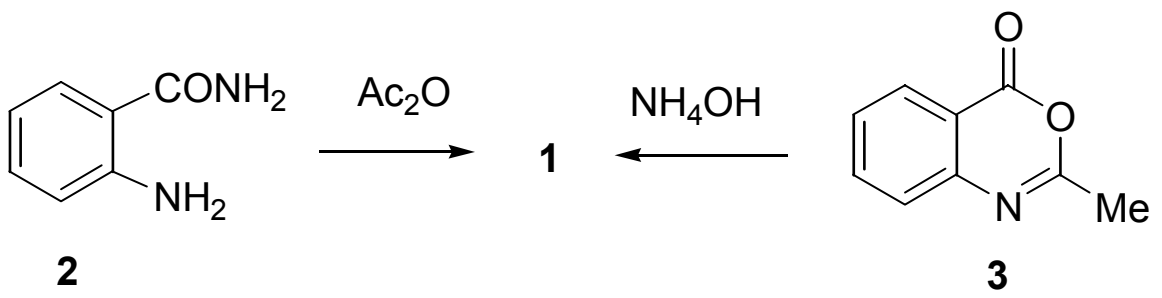

3

Scheme 1. Preparations of 2-acetamidobenzamide 1.<smiles>Cc1nc2ccccc2c(=O)[nH]1</smiles>

Greater awareness of the influence of crystal structure on the physical properties of crystalline molecular fine chemicals has stimulated much new research into crystal nucleation 
and crystallisation methods. Technologies such as co-crystallization ${ }^{12}$, supercritical fluid crystallization $^{13}$, sonocrystallization ${ }^{14}$, laser-induced crystal nucleation ${ }^{15}$ and capillary-space crystallization $^{16}$ are just some examples of recent innovations in this area. A complementary strategy is to attempt to influence crystal nucleation and growth at the molecular level, for example though epitaxial crystal growth on ordered substrates ${ }^{17}$ or though the use of additives. It has been shown that rationally-designed 'tailor-made' additives ${ }^{18}$ can be used to control the crystal form obtained from certain polymorphic systems. The design of these additives usually exploits some molecular or supramolecular feature of the crystallizing system. For example, conformational mimicry, introduced by Davey et al. ${ }^{19}$, is a strategy for the design of selective additives based on differences in molecular conformation between crystal forms. As a compound which exhibits variable crystal polymorphism based on differences in molecular conformation and hydrogen-bonding pattern between forms, 2-acetamidobenzamide $\mathbf{1}$ is an attractive subject for molecular-level crystallization control using additives. In our studies on compound 1, behaviour similar to that described by Barnett et al. ${ }^{10}$ was observed, i.e. for a considerable period the $\alpha$ form was the only crystal form of compound $\mathbf{1}$ obtained by us under all crystallization conditions attempted. The $\beta$ form was not observed by us until the work described below was well advanced. In this regard, the 2-acetamidobenzamide system has some of the characteristics of 'disappearing polymorphs' ${ }^{20}$. After completing our initial investigations based on the literature methods of preparing and recrystallizing compound $\mathbf{1}$, we therefore set out to design additives which would direct nucleation towards the $\beta$ form.

\section{Results and Discussion}

Samples of 2-acetamidobenzamide 1 were prepared by us using both of the literature routes mentioned above, i.e. by acetylation of anthranilamide $\mathbf{2}^{7,9}$ and by reaction of 2-methyl-4Hbenzo $[d][1,3]$ oxazin-4-one 3 with ammonium hydroxide solution ${ }^{8,9}$. The IR spectra and PXRD patterns of the majority of samples of compound $\mathbf{1}$ obtained by us by either route corresponded with the IR spectrum and PXRD pattern of the $\alpha$ polymorph reported by Errede et al. ${ }^{9}$ Recrystallization of samples of compound $\mathbf{1}$ from water, acetone, methanol or THF also gave crystals with IR spectra and PXRD patterns consistent with the $\alpha$ form. When the work described herein was nearing completion, some preparations of compound $\mathbf{1}$ via the acetylanthranil route gave crystals with IR spectra and PXRD patterns matching those reported ${ }^{9}$ for the $\beta$ polymorph. Crystals of the $\beta$ polymorph were also subsequently obtained by recrystallization from acetone and from methanol. Typical examples of the IR spectra and PXRD patterns obtained by us for the $\alpha$ and $\beta$ forms are shown in Figure 2. In our hands, attempted melt recrystallizations of 2-acetamidobenzamide resulted in partial decomposition of the samples, giving mixtures of compounds and crystal forms. 

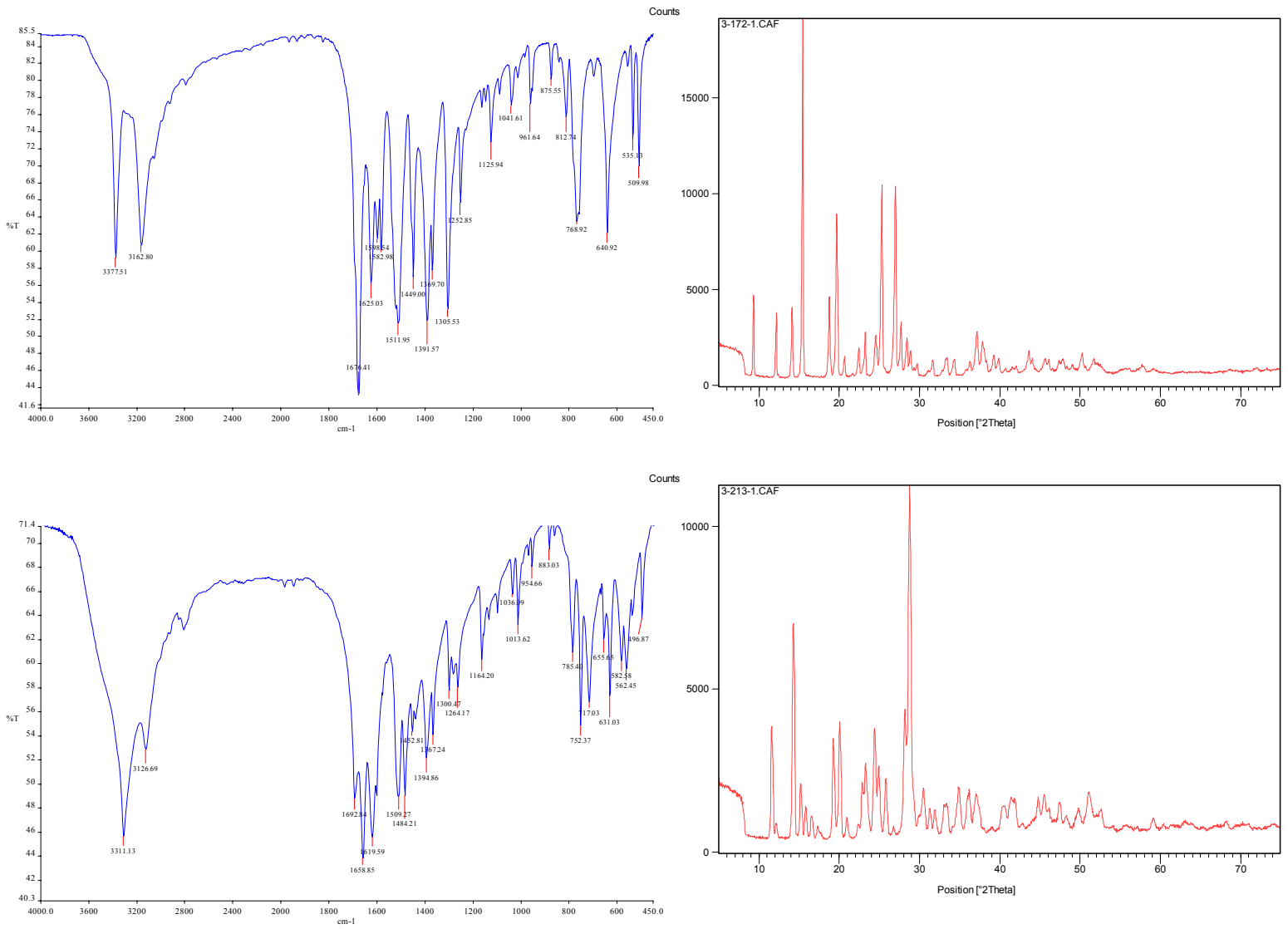

Figure 2. IR spectra (left) and PXRD patterns (right) of the $\alpha$ (top) and $\beta$ (bottom) crystal polymorphs of 2-acetamidobenzamide $\mathbf{1}$.

A relatively straightforward approach to the design of additives for 2-acetamidobenzamide crystallization would be to use substituted 2-acetamidobenzamides. Analogues of 2acetamidobenzamide bearing halogen substitutents on the benzene ring could be capable of selectively disrupting crystal nucleation and growth. To investigate this possibility, we prepared derivatives of compound $\mathbf{1}$ which were chlorinated at the 4- and 5-positions, i.e. compounds 8 and 9 respectively, from the corresponding acetylanthranil derivatives (Scheme 2). The effects of both compounds 8 and $\mathbf{9}$ as additives in recrystallizations of 2-acetamidobenzamide $\mathbf{1}$ were examined (Table 1, Entries 1, 2 and 3). 


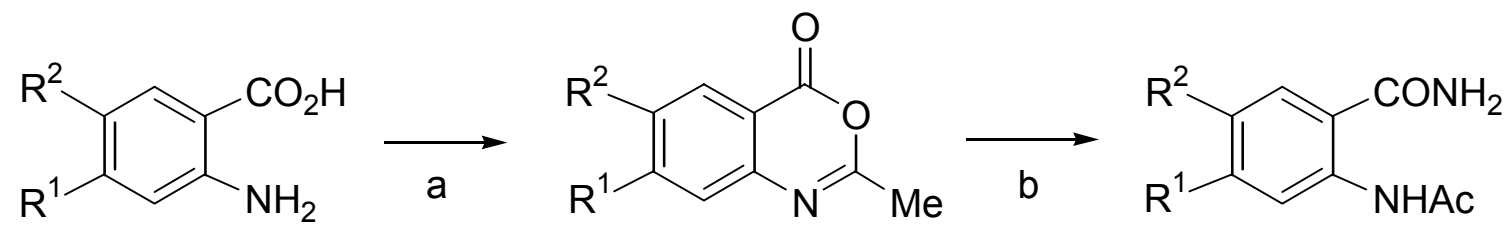
4: $\mathrm{R}^{1}=\mathrm{Cl} ; \mathrm{R}^{2}=\mathrm{H}$
6: $\mathrm{R}^{1}=\mathrm{Cl} ; \mathrm{R}^{2}=\mathrm{H}$
8: $\mathrm{R}^{1}=\mathrm{Cl} ; \mathrm{R}^{2}=\mathrm{H}$
5: $\mathrm{R}^{1}=\mathrm{H} ; \mathrm{R}^{2}=\mathrm{Cl}$
7: $\mathrm{R}^{1}=\mathrm{H} ; \mathrm{R}^{2}=\mathrm{Cl}$
9: $\mathrm{R}^{1}=\mathrm{H} ; \mathrm{R}^{2}=\mathrm{Cl}$

Scheme 2. Preparation of 4- and 5-chlorinated 2-acetamidobenzamide analogues 8 and 9. a) $\mathrm{Ac}_{2} \mathrm{O}, \Delta, 1 \mathrm{~h}(6: 69 \%, 7: 78 \%)$. b) $35 \%$ aq. $\mathrm{NH}_{4} \mathrm{OH}, 4$ h, room temp. (8: 71\%, 9: 42\%).

Table 1. Effect of addition of compounds 8, 9, 13, 14, 18 and 19 as additives in recrystallizations of 2-acetamidobenzamide $\mathbf{1}^{\mathrm{a}}$

\begin{tabular}{lllll}
\hline Entry & Solvent & Additive No. & $\begin{array}{l}\text { w/w additive } \\
\text { used }\end{array}$ & $\begin{array}{l}\text { Crystal form } \\
\text { obtained }\end{array}$ \\
\hline 1 & $\mathrm{MeOH}$ & $\mathbf{8}$ & $10 \%$ & $\mathbf{4}$ (anhyd) \\
2 & Acetone & $\mathbf{8}$ & $10 \%$ & $\mathbf{4}($ anhyd) \\
3 & $\mathrm{MeOH}$ & $\mathbf{9}$ & $10 \%$ & $\mathbf{1}(\alpha)$ \\
4 & Acetone & $\mathbf{1 3}$ & $10 \%$ & $\mathbf{1}(\alpha)$ \\
5 & $\mathrm{H}_{2} \mathrm{O}$ & $\mathbf{1 3}$ & $10 \%$ & $\mathbf{1}(\alpha)$ \\
6 & $\mathrm{Acetone}$ & $\mathbf{1 4}$ & $10 \%$ & $\mathbf{1}(\alpha)$ \\
7 & $\mathrm{H}_{2} \mathrm{O}$ & $\mathbf{1 4}$ & $10 \%$ & $\mathbf{1}(\alpha)^{[\mathrm{b}]}$ \\
8 & $\mathrm{H}_{2} \mathrm{O}$ & $\mathbf{1 4}$ & $1 \%$ & $\mathbf{1}(\alpha)$ \\
9 & $\mathrm{MeOH}$ & $\mathbf{1 8}$ & $10 \%$ & $\mathbf{1}(\alpha)$ \\
10 & $\mathrm{H}_{2} \mathrm{O}$ & $\mathbf{1 8}$ & $10 \%$ & $\mathbf{1}(\alpha)$ \\
11 & $\mathrm{MeOH}$ & $\mathbf{1 9}$ & $10 \%$ & $\mathbf{1}(\alpha)^{[\mathrm{c}]}$ \\
12 & $\mathrm{H}_{2} \mathrm{O}$ & $\mathbf{1 9}$ & $10 \%$ & $\mathbf{1}(\alpha)^{[\mathrm{c}]}$ \\
\hline
\end{tabular}

${ }^{a}$ All recrystallizations were carried out in $100 \mathrm{~mL}$ conical flasks using $1.0 \mathrm{~g}$ of 2acetamidobenzamide 1 dissolved in a minimum amount of hot solvent. ${ }^{b}$ Fine crystallites giving IR spectra consistent with the $\alpha$ form of 1 , but giving anomalous PXRD patterns; see text for discussion. ${ }^{c}$ Fine needle-like crystallites

The material obtained by attempted recrystallization of compound $\mathbf{1}$ from either methanol or acetone in the presence of $10 \% \mathrm{w} / \mathrm{w}$ of compound 8 was found to be crystals of 2methylquinazol-4-one 4. As compound 4 itself exists in anhydrous and hydrate crystal forms, samples of both the anhydrous and monohydrate forms of $\mathbf{4}$ were prepared by literature methods $^{11}$ and the IR spectra and PXRD patterns of both forms recorded (Figure 3). By comparison with these, the 2-methylquinazol-4-one 4 material obtained by attempted recrystallization in the presence of compound $\mathbf{8}$ was found to be the anhydrous form. 2- 
Acetamidobenzamide $\mathbf{1}$ is known to be thermally labile to intramolecular condensation to give $4^{5,9,11}$. In the attempted recrystallizations of $\mathbf{1}$ in the presence of 2-acetamido-4-chlorobenzamide $\mathbf{8}$, compound $\mathbf{8}$ may be acting as non-polymorph-selective crystallization inhibitor. Compound $\mathbf{1}$ is then retained in solution, facilitating intramolecular condensation to compound $\mathbf{8}$. Addition of $10 \% \mathrm{w} / \mathrm{w}$ of 2 -acetamido-5-chlorobenzamide 9 to recrystallization of $\mathbf{1}$ from methanol was found to have no effect on the resulting crystal form, i.e. the $\alpha$ polymorph of compound 1 was obtained (Table 1; Entry 3).
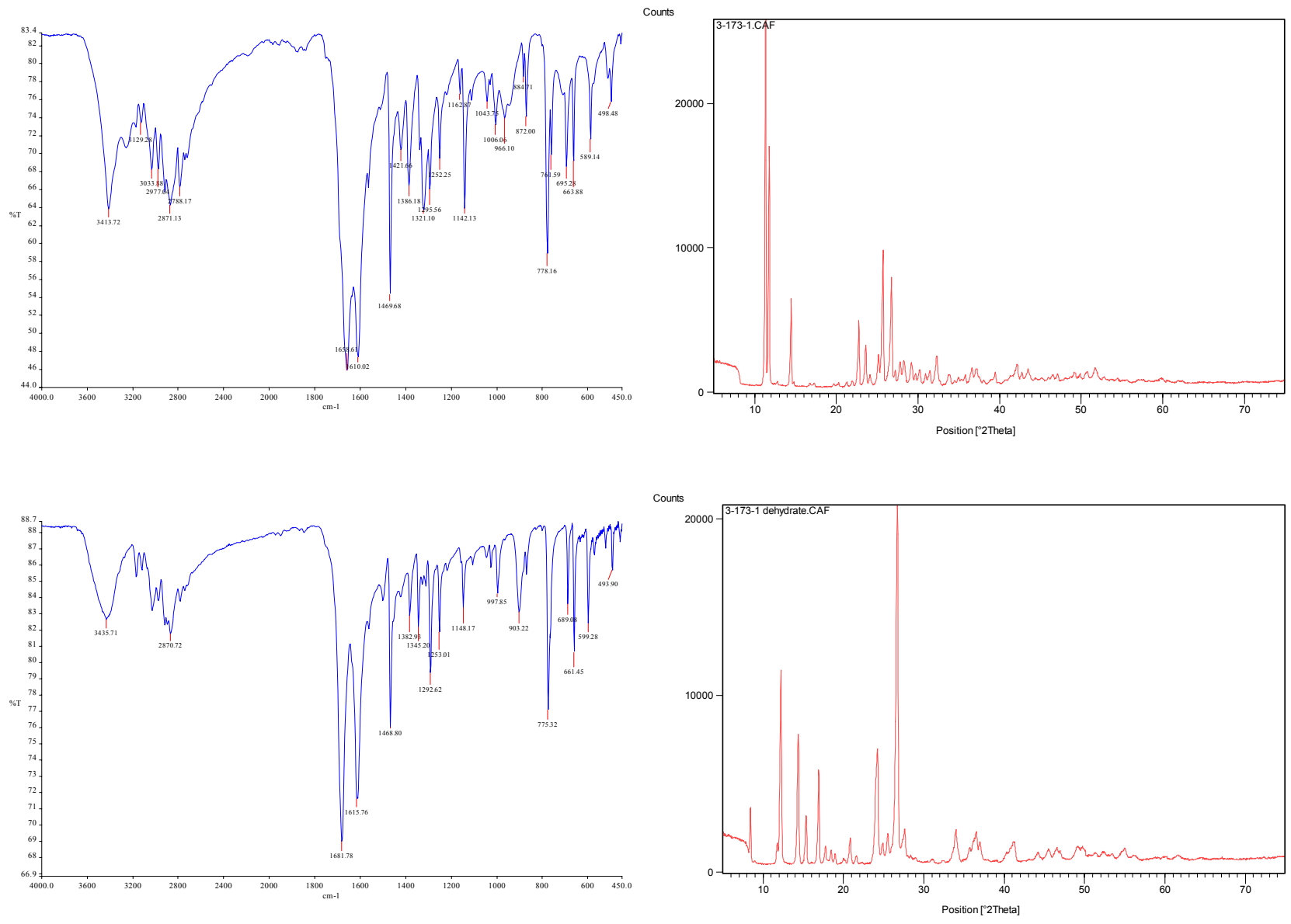

Figure 3. IR spectra (left) and PXRD patterns (right) of the monohydrate (top) and anhydrate (bottom) crystal modifications of 2-methylquinazol-4-one 4.

The distinct differences in molecular conformation between the $\alpha$ and $\beta$ polymorphs of compound 1 make conformational mimicry an attractive strategy for the design of crystallization controlling additives. As illustrated in Figure 1, the conformation characteristic of the $\alpha$ polymorph involves 2-acetamidobenzamide molecules which are close to being planar, while in the $\beta$ polymorph the amide groups are distinctly out of the plane of the benzene ring. Additives 
which could mimic the conformation observed in the $\beta$ form, but which could not adopt the conformation observed in the $\alpha$ form, could direct crystal nucleation toward the thermodynamically preferred $\beta$ form, by-passing the kinetically preferred $\alpha$ form. A constrained mimic of the $\beta$-form conformation could be obtained by replacing both of the similarly orientated secondary and primary amide hydrogens by a bridging unit intended to fix the amide groups in the required conformation. Preliminary modelling studies suggested that an ethano bridge would be too flexible to confer the required conformational constraint and that an etheno bridge would be preferable. It was chosen instead to use an ortho-disubstituted benzene ring as the bridging unit, giving 5-acetyl-10,11-dihydro-5H-dibenzo[b,e]-1,4-diazepin-11-one 14 as the putative additive. An energy minimized model $^{21}$ of compound 14, shown in Figure 4, suggests that the torsional angle in compound $\mathbf{1 4}$ equivalent to $\tau_{1}$ of the $\beta$-form of compound $\mathbf{1}$ is $151.0^{\circ}$, while the angle similarly corresponding to $\tau_{2}$ is $130.6^{\circ}$. This would constitute good correspondence between the $\tau_{1}$ values for the $\beta$ conformation of 1 and mimic 14, and modest correspondence for the $\tau_{2}$.values. Moreover, the bridging benzene ring fixes the orientation of both amide groups in the same direction, as in the $\beta$ conformation of $\mathbf{1}$. Compound $\mathbf{1 4}$ was prepared by modification of a literature route 22 as outlined in Scheme 3.

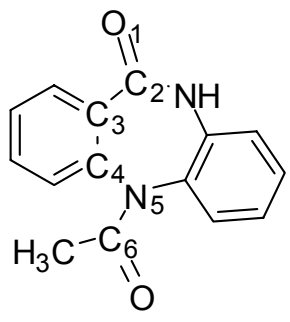

14

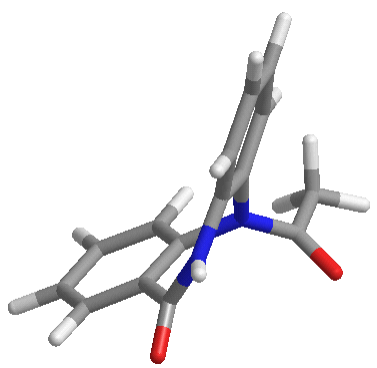

Figure 4. Structure and energy minimised conformation of 5-acetyl-10,11-dihydro-5Hdibenzo[b,e]-1,4-diazepin-11-one 14. Torsional angles $\tau_{1}$ and $\tau_{2}$ referred to in the text are defined by atoms $\mathrm{O}_{1}-\mathrm{C}_{2}-\mathrm{C}_{3}-\mathrm{C}_{4}$ and $\mathrm{C}_{3}-\mathrm{C}_{4}-\mathrm{N}_{5}-\mathrm{C}_{6}$ respectively. 


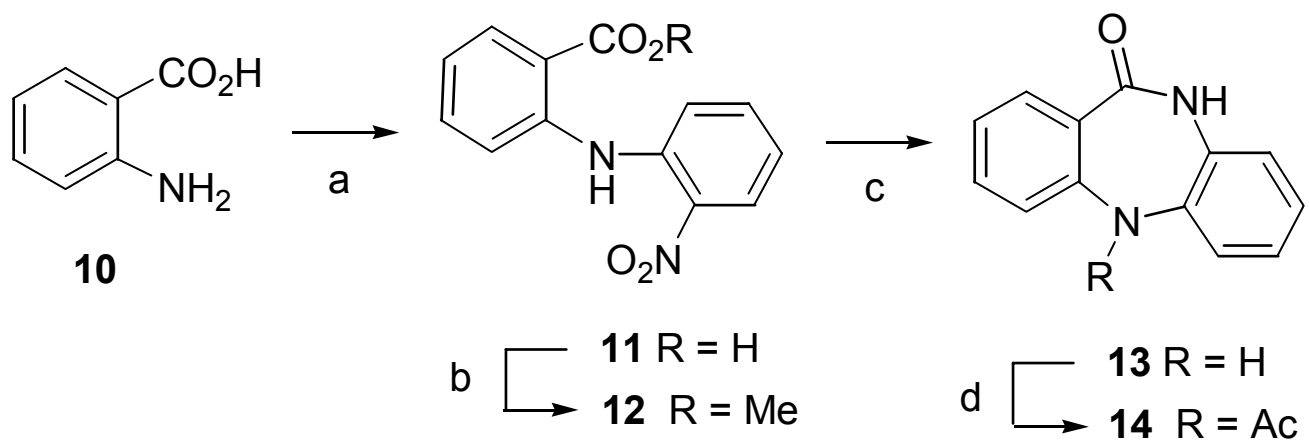

Scheme 3. Synthesis of 5-acetyl-10,11-dihydro-5H-dibenzo[b,e]-1,4-diazepin-11-one 14. (a) 1bromo-2-nitrobenzene, $\mathrm{K}_{2} \mathrm{CO}_{3}, \mathrm{Cu}$ bronze, $n \mathrm{BuOH}, \Delta, 16 \mathrm{~h},\left(11: 68 \%\right.$ ); (b) $\mathrm{SOCl}_{2}, \mathrm{MeOH}, \Delta, 16$ h, (12: 67\%); (c) Sn, $3 \mathrm{M}$ aq. $\mathrm{HCl}, \Delta, 20$ h, (13: 81\%); (d) $\mathrm{Ac}_{2} \mathrm{O}$, conc. $\mathrm{H}_{2} \mathrm{SO}_{4}, \Delta, 10$ min, (14: $73 \%)$.

The additive effects of both the 10,11-dihydro-5H-dibenzo[b,e]-1,4-diazepin-11-one 13 and the 5-acetyl-10,11-dihydro-5H-dibenzo[b,e]-1,4-diazepin-11-one 14 on 2-acetamidobenzamide 1 recrystallization were investigated. Compound $\mathbf{1 3}$ had no observable effect on the outcome of 2acetamidobenzamide 1 recrystallizations from acetone or ethanol, crystals of the $\alpha$ form being obtained (Table 1, Entries 4 and 5). Addition of 5-acetyl-10,11-dihydro-5H-dibenzo[b,e]-1,4diazepin-11-one 14 to recrystallizations of 1 from acetone likewise had no observable effect, again giving crystals of the $\alpha$ form (Table 1, Entry 6). However, addition of $10 \% \mathrm{w} / \mathrm{w}$ 5-acetyl10,11-dihydro-5H-dibenzo[b,e]-1,4-diazepin-11-one 14 to recrystallizations of compound 1 from water had an effect on the morphology of the resulting crystals (Table 1, Entry 7). Whereas crystals of compound $\mathbf{1}$ obtained from the recrystallizations described above were distinct needles, the crystals produced by recrystallization in the presence of $10 \% \mathrm{w} / \mathrm{w}$ of compound 14 were small crystallites with no distinctive morphology. The infra-red spectrum of these crystals were consistent with their being crystals of the $\alpha$ polymorph of $\mathbf{1}$. However, the PXRD pattern of this material was significantly different to that previously obtained for the $\alpha$ form of compound $\mathbf{1}$, nor was it consistent with the PXRD patterns of the $\beta$ form of compound $\mathbf{1}$ or of either form of compound 4. Gross changes in crystal morphology can result in significant changes to the intensities of reflections in PXRD patterns, and incorporation of sufficient quantities of additive compound can also give rise to additional reflections. Hence, this material may be crystals of the $\alpha$ form of 2-acetamidobenzamide with considerable inclusion of additive 14. Extensive inclusion of additive would also be consistent with the observed change in morphology. When the amount of compound 14 added was reduced to $1 \% \mathrm{w} / \mathrm{w}$, the modified crystal morphology was no longer observed and needle-like crystals of the $\alpha$ form of 1 were obtained (Table 1, Entry 8).

An essential difference between the polymorphs of compound $\mathbf{1}$ is the presence of an intramolecular hydrogen bond in molecules of the $\alpha$ form. Theoretical studies have shown that the intramolecular hydrogen bonded conformation present in the $\alpha$ form is more stable than the conformation present in the $\beta$ form $^{6}$. This conformation may be preferred in solution, which may 
be associated with a possible kinetic preference for the $\alpha$ form. Formation of 2acetamidobenzamide by methods which hinder the formation of the intramolecular hydrogen bond could result in preferential crystallization of the $\beta$ form. Barnett et al. found that the $\beta$ form was first obtained by them after attempted preparation of the N-deuterated derivative $15^{10}$, which may be a consequence of disruption of the intramolecular hydrogen bond by the deuteration process. A similar effect could be achieved by temporary in situ replacement of the $\mathrm{N}-\mathrm{H}$ groups by $\mathrm{N}$-trimethylsilyl groups. In situ generation of $\mathrm{N}$-trimethylsilyl groups has been used to assist the solubilization of polar amines in apolar solvents, and to activate less nucleophilic amines towards reaction with electrophiles ${ }^{23}$. Direct trimethylsilylation of 2-acetamidobenzamide by treatment with chlorotrimethylsilane and triethylamine in hot chloroform gave, after cooling, a mixture of 2-acetamidobenzamide $\mathbf{1}$ and 2-methylquinazol-4-one 4, necessitating chromatographic separation. An indirect trimethylsilylation was attempted by reaction of 2methyl-4H-benzo[d] [1,3]oxazin-4-one 3 with tris(trimethylsilyl)amine at room temperature. This gave crystals of the anhydrous form of 2-methylquinazol-4-one 4. It appears that intramolecular condensation of 2-acetamidobenzamide $\mathbf{1}$ to compound $\mathbf{4}$ is facilitated by the dehydrating effect of trimethylsilylating agents. In order to assess whether the conversion tris(trimethylsily)amine mediated conversion to $\mathbf{3}$ to $\mathbf{4}$ was in any way general, 2-phenyl-4H-benzoxazin-4-one $\mathbf{1 6}$ was prepared and subjected to the same conditions, however no reaction was observed. Compound $\mathbf{1 6}$ reacted with aqueous ammonia in a like manner to acetylanthranil, giving 2benzoylamidobenzamide 17.

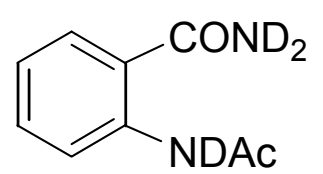

15

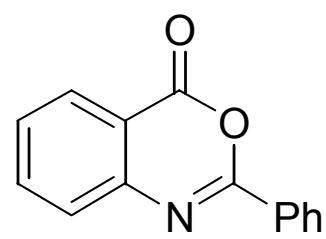

16<smiles>NC(=O)c1ccccc1NC(=O)c1ccccc1</smiles>

17

The differences in hydrogen bonding pattern between the $\alpha$ and $\beta$ forms of 1 could also be used as the basis for design of alternative conformational mimics. Replacement of the secondary amido $\mathrm{N}-\mathrm{H}$ group with acyl groups, for example, would give imido analogues which retain most of the supramolecular binding features of compound $\mathbf{1}$ but which cannot form an intramolecular hydrogen N-H...O bond. To assess this possibility, we prepared 2-phthalimidobenzoic acid 18 and 2-phthalimidobenzamide 19. Both of these compound can exist in a conformation which mimics that of the $\beta$ form of 2-acetamidobenzamide (Figure 5), but cannot exist in an conformation which mimics the $\alpha$ form. When added to recrystallizations of $\mathbf{1}$ from either methanol or water, neither $\mathbf{1 8}$ nor $\mathbf{1 9}$ affected the polymorphic outcome, the $\alpha$ form being obtained (Table 1, Entries 9 to 12). However, compound 19 had a distinct affect on the morphology of the resulting crystals (Table 1, Entries 11 and 12). Those obtained in the presence of compound $\mathbf{1 8}$ had the typical morphology of crystals of $\mathbf{1}$, being needles of approximately 0.5 
to $1.0 \mathrm{~cm}$ length. Those obtained in the presence of compound $\mathbf{1 9}$, from both methanol and water, had a similar needle-like habit but with significantly reduce dimensions, typically $<0.1$ $\mathrm{cm}$ in length.

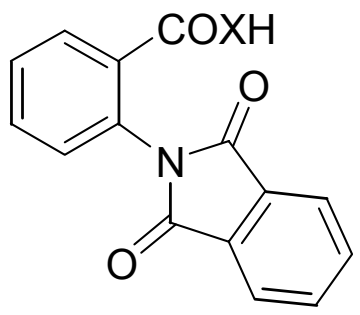

18: $X=O$

19: $\mathrm{X}=\mathrm{NH}$

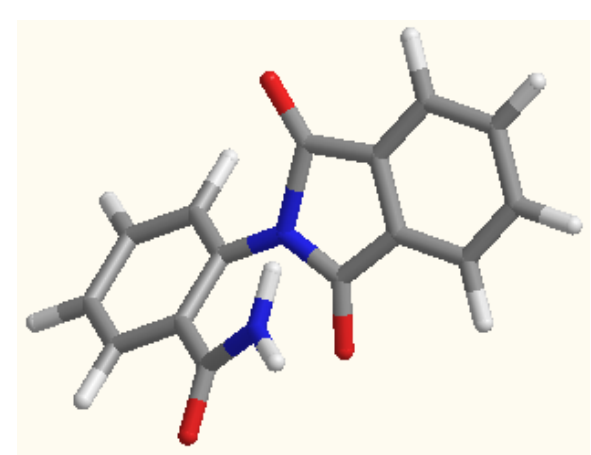

Figure 5. Putative conformation of compound 19 mimicking the $\alpha$ form conformation of 2acetamidobenzamide.

\section{Conclusions}

Despite having relatively simple molecular structures, 2-acetamidobenzamide $\mathbf{1}$ and 2 methylquinazol-4-one $\mathbf{4}$ display a variety of complexities in their solid state chemistry, including crystal polymorphism, hydrates, conformational polymorphism, variation in hydrogen-bonding networks, kinetic $v s$. thermodynamic control, solid-state molecular transformation, and variable and unpredictable crystallization outcomes. As the $\alpha$ and $\beta$ crystal polymorphs of $\mathbf{1}$ differ in both in molecular conformation and in hydrogen-bonding networks, compound $\mathbf{1}$ is ostensibly a good candidate system for crystallization control using additives designed to exploit conformational and hydrogen-bonding features. Our studies using additives of design based on steric, conformational or hydrogen bonding considerations were not successful in inducing nucleation of the $\beta$ form in preference to the $\alpha$. As the $\alpha$ form appears to be preferred kinetically, inhibitors designed to selectively bind to pre-critical nuclei of this form may be more effective in increasing the size of critical nuclei and decreasing the nucleation rate. Additives designed to 
induce the $\beta$ form may not significantly interact with $\alpha$ form nuclei. An additional feature of the 2-acetamidobenzamide (1) / 2-methylquinazol-4-one (4) system is the ease with which compound 1 undergoes intramolecular condensation to 4 . Inhibition of nucleation and growth of crystals of $\mathbf{1}$ from solution has a tendency result in formation of $\mathbf{4}$ rather than providing an opportunity to direct crystallization of compound 1. Our experience with 2acetamidobemnzamide was similar to that of Barnett et al. ${ }^{10}$ in that the most important factor in determining polymorphic outcome was the timing of the crystallization experiments within the study, the $\alpha$ form being obtained exclusively by us for most of the duration of our study, the $\beta$ form being obtained later in the study and subsequently often being obtained by methods which had previously provided the $\alpha$ form.

\section{Experimental Section}

General Procedures. All materials were purchased from Sigma-Aldrich. Melting points were determined on a Reichert hot-stage microscope and are uncorrected. Infrared spectra (pressed $\mathrm{KBr}$ discs) were recorded on a Perkin-Elmer 1000 spectrometer or on a Perkin Elmer Spectrum One FT-IR spectrometer in the range 4000 to $500 \mathrm{~cm}^{-1}$. ${ }^{1} \mathrm{H}$ NMR spectra were recorded at 300 $\mathrm{MHz}$ and ${ }^{13} \mathrm{C}$ NMR spectra were recorded at $75 \mathrm{MHz}$ on a Bruker Avance 300 spectrometer. Thin layer chromatography (TLC) was performed on Merck aluminium sheets coated with silica gel $60 \mathrm{~F}_{254}$. Chromatographs were visualised under ultraviolet light. Flash column chromatography was performed on silica gel 60 (Fluka, 220-440 mesh). High resolution precise mass spectra (HRMS) were recorded on a Waters LCT Premier LC-MS instrument in electrospray ionisation (ESI) positive mode using $50 \%$ acetonitrile-water containing $0.1 \%$ formic acid as eluent; samples were made up in acetonitrile. Powder X-ray diffraction was performed using a Philips PANalytical X'Pert PRO diffractometer with a PW 3830 generator, a PW 3710 MPD diffractometer and an X'Celerator detector operated with an anode current of 40 $\mathrm{mA}$ and an accelerating voltage of $45 \mathrm{kV}$. Samples were ground into powder and back-filled into aluminium holders and exposed to $\mathrm{Cu}-K_{\alpha}$ radiation at diffraction angles $(2 \theta)$ from $5^{\circ}$ to $75^{\circ}$ in continuous scan mode using a step size of $0.0167^{\circ}$ and a step time of $10.16 \mathrm{~s}$.

Preparation of 2-acetamidobenzamide 1 ( $\alpha$ polymorph) from anthranilamide. A mixture of anthranilamide 2 (1.36 g, $10 \mathrm{mmol})$ and acetic anhydride $(30 \mathrm{~mL})$ was stirred at $0^{\circ} \mathrm{C}$ for 15 minutes. The solid initially dissolved and this was followed by the formation of a precipitate. The product was isolated by filtration to yield a beige coloured, needle shaped crystalline solid (1.25 g, $7.01 \mathrm{mmol}, 70 \%$ ), m.p. $179-185^{\circ} \mathrm{C}$ (lit. ${ }^{9} 179-180^{\circ} \mathrm{C}\left[\alpha\right.$ polymorph]). $v_{\max }\left(\mathrm{KBr} / \mathrm{cm}^{-1}\right)$,

3378 and $3163\left(\mathrm{NH}_{2}\right), 1676(\mathrm{CONH}), 1625\left(\mathrm{CONH}_{2}\right) ;{ }^{1} \mathrm{H} \mathrm{NMR}\left(300 \mathrm{MHz}, \mathrm{CDCl}_{3}\right): \delta=2.21$ (s, $3 \mathrm{H}, \mathrm{CH}_{3}$ ), 5.62 (br s, $\left.1 \mathrm{H}, \mathrm{NH}\right), 6.15$ (br s, $\left.1 \mathrm{H}, \mathrm{NH}_{2}\right), 7.09$ (dt, ${ }^{3} J=8.16 \mathrm{~Hz},{ }^{4} J 1.14=\mathrm{Hz}, 1 \mathrm{H}$, Ar4-H), 7.48-7.54 (m, 2H, Ar3-H and Ar5-H), 8.64 (dd, $\left.1 \mathrm{H},{ }^{3} J=8.81 \mathrm{~Hz},{ }^{4} J=1.14 \mathrm{~Hz}, \operatorname{Ar} 6-\mathrm{H}\right)$, 11.11 (br s, $1 \mathrm{H}, \mathrm{NH})$. 
Preparation of 2-acetamidobenzamide 1 ( $\alpha$ polymorph) from 2-methyl-4Hbenzo[d][1,3]oxazin-4-one. 2-Methyl-4H-benzo[d][1,3]oxazin-4-one ${ }^{24}(3.00 \mathrm{~g}, 18.6 \mathrm{mmol})$ was added to a stirring solution of $35 \%$ ammonium hydroxide $(50 \mathrm{~mL})$. The needle like crystals dissolved instantly and a cream coloured solid was seen to precipitate simultaneously. The product was isolated by filtration to give a cream coloured solid $(2.01 \mathrm{~g}, 61 \%)$, m.p. $180-185^{\circ} \mathrm{C}$ (lit. ${ }^{9} 179-180^{\circ} \mathrm{C}\left[\alpha\right.$ polymorph]); $v_{\max }$ and $\delta_{\mathrm{H}}$ as above.

Preparation of 2-acetamidobenzamide 1 ( $\beta$ polymorph $)$ from 2-methyl-4Hbenzo $[\boldsymbol{d}][1,3]$ oxazin-4-one. An aqueous solution of ammonia $\left(32 \% \mathrm{NH}_{3}, 20 \mathrm{~mL}\right)$ was added to 2-methyl-4H-benzo[ $[d][1,3]$ oxazin-4-one $^{24}(1.0 \mathrm{~g}, 6.2 \mathrm{mmol})$. The resulting solution was stirred for $2 \mathrm{~h}$. The precipitate that formed was isolated by filtration and dried to afford the title compound as a white solid $(0.37 \mathrm{~g}, 34 \%) ; \mathrm{m} . \mathrm{p} .=186-188^{\circ} \mathrm{C}\left[\mathrm{lit}^{9} 189-190^{\circ} \mathrm{C}\right] ; v_{\max }(\mathrm{KBr}): 3311$, $3128,1659,1621,1512,1484,1452,1394,1367 \mathrm{~cm}^{-1} ;{ }^{1} \mathrm{H}$ NMR (300 MHz, DMSO-d 6 ): $\delta=2.03$ $\left(3 \mathrm{H}, \mathrm{s}, \mathrm{CH}_{3}\right), 7.08(1 \mathrm{H}, \mathrm{t}, J=8.2 \mathrm{~Hz}, \mathrm{ArH}), 7.49(1 \mathrm{H}, \mathrm{t}, J=8.2 \mathrm{~Hz}, \mathrm{ArH}), 7.72(1 \mathrm{H}, \mathrm{bs}, \mathrm{NH})$, $7.79(1 \mathrm{H}, \mathrm{d}, J=7.9 \mathrm{~Hz}, \mathrm{ArH}), 8.26(1 \mathrm{H}, \mathrm{bs}, \mathrm{NH}), 8.44(1 \mathrm{H}, \mathrm{d}, J=7.9 \mathrm{~Hz}, \mathrm{ArH}), 11.11(1 \mathrm{H}, \mathrm{bs}$, ArNH) ppm.

7-Chloro-2-methyl-4H-benzo[d][1,3]oxazin-4-one (6). A solution of 2-amino-4-chlorobenzoic acid $4(1.0 \mathrm{~g}, 5.8 \mathrm{mmol})$ in acetic anhydride $(15 \mathrm{~mL})$ was heated to reflux for 1 hour. The reaction mixture was concentrated under reduced pressure to yield a beige coloured crystalline solid $(0.79 \mathrm{~g}, 69 \%)$; m.p. $229-232^{\circ} \mathrm{C}$ (with sublimation observed from $\left.198^{\circ} \mathrm{C}\right) ; v_{\max }\left(\mathrm{KBr} / \mathrm{cm}^{-1}\right)$, $1766(\mathrm{C}=\mathrm{O}), 1639(\mathrm{~N}=\mathrm{C}) ;{ }^{1} \mathrm{H}$ NMR $\left(300 \mathrm{MHz}, \mathrm{CDCl}_{3}\right): \delta=2.47\left(\mathrm{~s}, 3 \mathrm{H}, \mathrm{CH}_{3}\right), 7.47\left(\mathrm{dd},{ }^{3} J=\right.$ $\left.8.30 \mathrm{~Hz},{ }^{4} J=2.00 \mathrm{~Hz}, 1 \mathrm{H}, \operatorname{Ar} 5-\mathrm{H}\right), 7.55(\mathrm{~d}, J=2.00 \mathrm{~Hz}, 1 \mathrm{H}, \mathrm{Ar} 3-\mathrm{H}), 8.12(\mathrm{~d}, J=8.30 \mathrm{~Hz}, 1 \mathrm{H}$, Ar6-H) ppm. ${ }^{13} \mathrm{C}$ NMR $\left(75 \mathrm{MHz}, \mathrm{CDCl}_{3}\right): \delta=21.82\left(\mathrm{CH}_{3}\right), 115.43(-\mathrm{C}-\mathrm{C}=\mathrm{O}), 126.72(\mathrm{CH})$, $129.18(\mathrm{CH}), 130.14(\mathrm{CH}), 143.32$ (-C-Cl), 147.88 (-N-C-C-), 159.27 (-N=C-O-), $161.98(\mathrm{C}=\mathrm{O})$ ppm; HRMS (ESI): Exact mass calculated for $\mathrm{C}_{9} \mathrm{H}_{7} \mathrm{ClNO}_{2}\left[(\mathrm{M}+\mathrm{H})^{+}\right]$196.0165, found 196.0169.

6-Chloro-2-methyl-4H-benzo $[\boldsymbol{d}]\left[\mathbf{1 , 3}, \mathbf{H}\right.$ oxazin-4-one $\quad$ (7). ${ }^{25}$ A solution of 2-amino-5chlorobenzoic acid $5(1.00 \mathrm{~g}, 5.80 \mathrm{mmol})$ in acetic anhydride $(15 \mathrm{~mL})$ was heated to reflux for 1 hour. The reaction mixture was concentrated under reduced pressure to yield a beige coloured crystalline solid $(0.88 \mathrm{~g}, 78 \%)$, m.p. $220-228^{\circ} \mathrm{C}$ (with sublimation observed from $192^{\circ} \mathrm{C}$ ). $v_{\max }\left(\mathrm{KBr} / \mathrm{cm}^{-1}\right), 1761(\mathrm{C}=\mathrm{O}), 1649(\mathrm{~N}=\mathrm{C}) ;{ }^{1} \mathrm{H} \mathrm{NMR}\left(300 \mathrm{MHz}, \mathrm{CDCl}_{3}\right): \delta=2.47\left(\mathrm{~s}, 3 \mathrm{H}, \mathrm{CH}_{3}\right)$, $7.5(\mathrm{~d}, J=8.46 \mathrm{~Hz}, 1 \mathrm{H}, \mathrm{Ar} 3-\mathrm{H}), 7.74\left(\mathrm{dd},{ }^{3} J=8.50 \mathrm{~Hz},{ }^{4} J=2.43 \mathrm{~Hz}, 1 \mathrm{H}, \mathrm{Ar} 4-\mathrm{H}\right), 8.15$ (d, $J=$ $2.50 \mathrm{~Hz}, 1 \mathrm{H}, \mathrm{Ar} 6-\mathrm{H})$ ppm. ${ }^{13} \mathrm{C}$ NMR $\left(75 \mathrm{MHz}, \mathrm{CDCl}_{3}\right): \delta=21.73\left(\mathrm{CH}_{3}\right), 118.18(-\mathrm{C}-\mathrm{C}=\mathrm{O})$, $128.17(\mathrm{CH}), 128.43(\mathrm{CH}), 134.21$ (-C-Cl), $137.2(\mathrm{CH}), 149.29$ (-N-C-C-), 158.98 (-N=C-O-), $160.84(\mathrm{C}=\mathrm{O})$ ppm. HRMS (ESI): Exact mass calculated for $\mathrm{C}_{9} \mathrm{H}_{7} \mathrm{ClNO}_{2}\left[(\mathrm{M}+\mathrm{H})^{+}\right]$196.0165, found 196.0165 .

2-Acetamido-4-chlorobenzamide (8). 7-Chloro-2-methyl-4H-benzo[d][1,3]oxazin-4-one $\mathbf{6}$ $(2.00 \mathrm{~g}, 10.22 \mathrm{mmol})$ was stirred for 4 hours of $35 \%$ ammonium hydroxide $(50 \mathrm{~mL})$. The 
resulting precipitate was isolated by filtration to yield a white crystalline solid (1.55 g, 71\%), m.p. $212-220^{\circ} \mathrm{C} . v_{\max }\left(\mathrm{KBr} / \mathrm{cm}^{-1}\right), 3366$ and $3175\left(\mathrm{NH}_{2}\right), 1663(\mathrm{CONH}), 1618\left(\mathrm{CONH}_{2}\right) ;{ }^{1} \mathrm{H}$ NMR (300 MHz, DMSO-d 6 ): $\delta=2.11\left(\mathrm{~s}, 3 \mathrm{H}, \mathrm{CH}_{3}\right), 7.20\left(\mathrm{dd},{ }^{3} J=9.0 \mathrm{~Hz},{ }^{4} J=3.0 \mathrm{~Hz}, 1 \mathrm{H}, \mathrm{Ar} 5-\right.$ H), 7.80 (d, $J=9.0 \mathrm{~Hz}, 1 \mathrm{H}, \operatorname{Ar} 6-\mathrm{H}), 7.84$ (br d, 1H, NH), 8.34 (br s, $1 \mathrm{H}, \mathrm{NH}), 8.56$ (d, $J=3.0$ $\mathrm{Hz}, 1 \mathrm{H}, \mathrm{Ar} 3-\mathrm{H}), 11.23$ (br s, $1 \mathrm{H}, \mathrm{NH}) \mathrm{ppm} .{ }^{13} \mathrm{C}$ NMR $\left(75 \mathrm{MHz}, \mathrm{DMSO}-\mathrm{d}_{6}\right): \delta=24.95\left(\mathrm{CH}_{3}\right)$, $117.94\left(-\underline{\mathrm{C}}-\mathrm{C}=\mathrm{O}-\mathrm{NH}_{2}\right), 119.23(\mathrm{CH}), 122.00(\mathrm{CH}), 130.24(\mathrm{CH}), 130.24(-\mathrm{C}-\mathrm{Cl}), 140.85(-\underline{\mathrm{C}}-$ $\mathrm{NH}-\mathrm{C}=\mathrm{O}-), 168.83(-\mathrm{C}(\mathrm{O}) \mathrm{NH}-), 169.83\left(-\mathrm{C}(\mathrm{O}) \mathrm{NH}_{2}\right)$ ppm. HRMS (ESI): Exact mass calculated for $\mathrm{C}_{9} \mathrm{H}_{8} \mathrm{ClN}_{2} \mathrm{O}_{2}\left[(\mathrm{M}-\mathrm{H})^{-}\right]$211.0274, found 211.0279.

2-Acetamido-5-chlorobenzamide (9). ${ }^{22}$ 6-Chloro-2-methyl-4H-benzo $[d][1,3]$ oxazin-4-one 7 $(2.00 \mathrm{~g}, 10.22 \mathrm{mmol})$ was stirred for 4 hours in $35 \%$ ammonium hydroxide $(50 \mathrm{~mL})$. The resulting precipitate was isolated by filtration to yield a white crystalline solid $(0.92 \mathrm{~g}, 42 \%)$, m.p. $219-223^{\circ} \mathrm{C} . v_{\max }\left(\mathrm{KBr} / \mathrm{cm}^{-1}\right), 3319$ and $3185\left(\mathrm{NH}_{2}\right), 1673(\mathrm{CONH}), 1621\left(\mathrm{CONH}_{2}\right) ;{ }^{1} \mathrm{H}$ NMR $\left(300 \mathrm{MHz}, \mathrm{DMSO}_{-} \mathrm{d}_{6}\right): \delta=2.09\left(\mathrm{~s}, 3 \mathrm{H}, \mathrm{CH}_{3}\right), 7.54\left(\mathrm{dd},{ }^{3} J=9.0 \mathrm{~Hz},{ }^{4} J=3.0 \mathrm{~Hz} 1 \mathrm{H}, \mathrm{Ar} 4-\right.$ H), $7.81(\mathrm{~d}, J=3.0 \mathrm{~Hz}, 1 \mathrm{H}$, Ar6-H), 7.85 (br d, 1H, NH), 8.35 (br s, 1H, NH), 8.44 (d, 1H, $J=9$ $\mathrm{Hz}, \mathrm{Ar} 3-\mathrm{H}), 10.97$ (br s, $1 \mathrm{H}, \mathrm{NH}) \mathrm{ppm} .{ }^{13} \mathrm{C}$ NMR (75 MHz, DMSO-d 6 ): $\delta=24.84\left(\mathrm{CH}_{3}\right), 121.48$

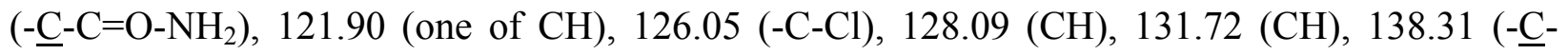
NHCO-), $168.31(\mathrm{C}(\mathrm{O}) \mathrm{NH}), 169.28\left(\mathrm{C}(\mathrm{O}) \mathrm{NH}_{2}\right) \mathrm{ppm}$. HRMS (ESI): Exact mass calculated for $\mathrm{C}_{9} \mathrm{H}_{10} \mathrm{ClN}_{2} \mathrm{O}_{2}\left[(\mathrm{M}+\mathrm{H})^{+}\right]$213.0431, found 213.0441.

2-Methylquinazol-4-one (4). A solution of 2-acetamidobenzamide $1(1.27 \mathrm{~g}, 7.13 \mathrm{mmol})$ in aqueous saturated sodium bicarbonate solution $(30 \mathrm{~mL})$ was heated to reflux for 2 hours. The precipitate which formed was isolated by filtration to yield a cream coloured crystalline solid (0.89 g, $4.99 \mathrm{mmol}, 70 \%)$, m.p. $241-248^{\circ} \mathrm{C}$ [Material appeared to sublime from $185^{\circ} \mathrm{C}$. On cooling and resolidifing, a much smaller quantity of the solid was observed.]; $v_{\max }\left(\mathrm{KBr} / \mathrm{cm}^{-1}\right)$, $3413(\mathrm{NH}), 1658(\mathrm{C}=\mathrm{O}), 1610(\mathrm{~N}=\mathrm{C}) ;{ }^{1} \mathrm{H}$ NMR $\left(300 \mathrm{MHz}, \mathrm{CDCl}_{3}\right): \delta=2.50\left(\mathrm{~s}, 3 \mathrm{H}, \mathrm{CH}_{3}\right), 7.41$ $\left(\mathrm{dt},{ }^{3} J=7.5 \mathrm{~Hz},{ }^{4} J=1.2 \mathrm{~Hz}, 1 \mathrm{H}, \mathrm{Ar} 5-\mathrm{H}\right), 7.61\left(\mathrm{~d}, J_{1}=7.5 \mathrm{~Hz}, \mathrm{Ar} 3-\mathrm{H}\right), 7.71\left(\mathrm{ddd},{ }^{3} J_{1}=8.3 \mathrm{~Hz}\right.$, $\left.{ }^{3} J_{2}=7.0 \mathrm{~Hz},{ }^{4} J=1.4 \mathrm{~Hz}, 1 \mathrm{H}, \mathrm{Ar} 4-\mathrm{H}\right), 8.21\left(\mathrm{dd},{ }^{3} J=8.0 \mathrm{~Hz},{ }^{4} J=1.5 \mathrm{~Hz}, 1 \mathrm{H}, \operatorname{Ar} 6-\mathrm{H}\right), 10.69$ (br s, 1H, NH). The IR spectrum and PXRD pattern obtained for this compound (Figure 3) is consistent with 2-methylquinazol-4-one monohydrate ${ }^{11}$. The product was then dried in an oven at $110^{\circ} \mathrm{C}$ for 2 days to give a white powder m.p. $235-241^{\circ} \mathrm{C}$ [Material appeared to sublime from $187^{\circ} \mathrm{C}$. On cooling and resolidifing, a much smaller quantity of the solid was observed.]; $\left.v_{\max }\left(\mathrm{KBr} / \mathrm{cm}^{-1}\right), 3435(\mathrm{NH}), 1681(\mathrm{C}=\mathrm{O}), 1615(\mathrm{~N}=\mathrm{C}) ; \mathrm{H}_{\mathrm{C}}\right), 8.28\left(1 \mathrm{H}, \mathrm{dd},{ }^{3} \mathrm{~J}=7.91,{ }^{4} \mathrm{~J}=1.31\right.$, $\mathrm{ArH}), 10.82(1 \mathrm{H}, \mathrm{br} \mathrm{s}, \mathrm{NH}) ;{ }^{1} \mathrm{H}$ NMR $\left(300 \mathrm{MHz}, \mathrm{CDCl}_{3}\right): \delta=2.57\left(\mathrm{~s}, 3 \mathrm{H}, \mathrm{CH}_{3}\right), 7.50\left(\mathrm{dt},{ }^{3} J=\right.$ $\left.7.5 \mathrm{~Hz},{ }^{4} J=1.2 \mathrm{~Hz}, 1 \mathrm{H}, \mathrm{Ar} 5-\mathrm{H}\right), 7.68(\mathrm{~d}, J=7.5 \mathrm{~Hz}, 1 \mathrm{H}, \mathrm{Ar} 3-\mathrm{H}), 7.78\left(\mathrm{ddd},{ }^{3} J_{1}=8.4 \mathrm{~Hz},{ }^{3} J_{2}=\right.$ $\left.7.0 \mathrm{~Hz},{ }^{4} J=1.4 \mathrm{~Hz}, 1 \mathrm{H}, \mathrm{Ar} 4-\mathrm{H}\right), 8.28\left(\mathrm{dd},{ }^{3} J=7.9 \mathrm{~Hz},{ }^{4} J=1.3 \mathrm{~Hz}, 1 \mathrm{H}, \operatorname{Ar} 6-\mathrm{H}\right), 10.82(1 \mathrm{H}$, br s, $\mathrm{NH})$. The IR spectrum and PXRD pattern of this material was consistent with those of anhydrous 2-methylquinazol-4-one ${ }^{11}$ (Figure 3).

2-(2-Nitrophenyl)aminobenzoic acid (11). A suspension of anthranilic acid $10(0.50 \mathrm{~g}, 3.60$ $\mathrm{mmol}), 1$-bromo-2-nitrobenzene $(0.74 \mathrm{~g}, 3.60 \mathrm{mmol})$, finely ground potassium carbonate $(0.50 \mathrm{~g}$, $3.60 \mathrm{mmol})$ and copper bronze $(0.50 \mathrm{~g})$ in $\mathrm{n}$-butanol $(20 \mathrm{~mL})$ was heated to reflux for 16 hours 
with mechanical stirring, after which the reaction mixture was filtered through celite and the solvent evaporated under reduced pressure to afford a dark red oil which was subjected to silica gel chromatography using dichloromethane:methanol as eluant to give the product as red crystals, $0.96 \mathrm{~g}(68 \%) ; \mathrm{m} . \mathrm{p} .208^{\circ} \mathrm{C}\left(\mathrm{lit}^{22} 206-214^{\circ} \mathrm{C}\right) ; v_{\max }\left(\mathrm{KBr} / \mathrm{cm}^{-1}\right) 3435(\mathrm{~N}-\mathrm{H}), 1668(\mathrm{C}=\mathrm{O})$, 1499, $1262\left(\mathrm{NO}_{2}\right) ;{ }^{1} \mathrm{H}$ NMR (300 MHz, DMSO-d 6 ): $\delta=7.04-7.11(\mathrm{~m}, 2 \mathrm{H}, \mathrm{ArH}$ x 2), 7.51-7.56 (m, 2H, ArH x 2), 7.57-7.66 (m, 2H, ArH x 2), $7.98\left(\mathrm{~d},{ }^{3} J=7.7 \mathrm{~Hz}, 1 \mathrm{H}, \mathrm{ArH}\right), 8.12\left(\mathrm{dd},{ }^{3} J=8.3\right.$ $\left.\mathrm{Hz},{ }^{4} \mathrm{~J}=1.3 \mathrm{~Hz}, 1 \mathrm{H}, \mathrm{ArH}\right), 11.12$ (br s, $\left.1 \mathrm{H}, \mathrm{NH}\right)$.

Methyl 2-(2-nitrophenyl)aminobenzoate (12). Thionyl chloride $(0.12 \mathrm{~g}, 1.08 \mathrm{mmol})$ was added dropwise to a stirring, ice-cooled solution of 2-(2-nitrophenyl)aminobenzoic acid $\mathbf{1 0}(0.20 \mathrm{~g}$, $0.77 \mathrm{mmol})$ in methanol $(20 \mathrm{~mL})$. The reaction mixture was allowed to warm to room temperature and then heated to reflux for 16 hours, after which the mixture was cooled on ice with subsequent precipitation of the product as an orange crystalline solid; $0.14 \mathrm{~g} \mathrm{(67 \% );} \mathrm{m.p.}$ $160-162^{\circ} \mathrm{C}\left(\mathrm{lit}^{21} 156-157^{\circ} \mathrm{C}\right) ; v_{\max }\left(\mathrm{KBr} / \mathrm{cm}^{-1}\right) 3436(\mathrm{~N}-\mathrm{H}), 1697(\mathrm{C}=\mathrm{O}), 1502,1253\left(\mathrm{NO}_{2}\right) ;{ }^{1} \mathrm{H}$ NMR (300 MHz, DMSO-d $\left.{ }_{6}\right): \delta=3.96\left(\mathrm{~s}, 3 \mathrm{H}, \mathrm{OCH}_{3}\right), 6.91-7.07$ (m, $\left.2 \mathrm{H}, \mathrm{ArH} \times 2\right), 7.42-7.64(\mathrm{~m}$, $4 \mathrm{H}, \operatorname{ArH}$ x 2), $8.05\left(\mathrm{dd}, 1 \mathrm{H},{ }^{3} J=8.5 \mathrm{~Hz},{ }^{4} J=1.5 \mathrm{~Hz}, \mathrm{ArH}\right), 8.17\left(\mathrm{dd}, 1 \mathrm{H},{ }^{3} J=8.5 \mathrm{~Hz},{ }^{4} J=1.5\right.$ $\mathrm{Hz}, \mathrm{ArH}), 11.13$ (br s, 1H, NH).

10,11-Dihydro-5 $H$-dibenzo $[b, e][1,4]$ diazepin-11-one (13). A suspension of methyl 2-(2nitrophenyl)aminobenzoate $(1.20 \mathrm{~g}, 4.41 \mathrm{mmol}) 12$ and granulated tin $(1.46 \mathrm{~g}, 12.32 \mathrm{mg}$ atom $)$ in $3 \mathrm{M}$ aqueous hydrochloric acid solution $(30 \mathrm{~mL})$ was heated to reflux for 20 hours, after which the suspension was filtered while still hot. The clear solution was cooled to $0^{\circ} \mathrm{C}$ and a solution of sodium hydroxide $(5.0 \mathrm{~g}, 0.13 \mathrm{mmol})$ in water $(12 \mathrm{~mL})$ which had been pre-cooled to $0^{\circ} \mathrm{C}$ was added. The solution was stirred for 10 minutes and the resulting solid precipitate was removed by filtration through celite and washed with dichloromethane $(20 \mathrm{~mL})$. The dichloromethane layer was separated and the aqueous layer further extracted with dichloromethane $(20 \mathrm{~mL})$. The combined dichloromethane solutions were dried over magnesium sulphate, filtered and the solvent evaporated to give the product as photosensitive yellow crystals $0.92 \mathrm{~g}(81 \%)$; m.p. $131-133^{\circ} \mathrm{C}\left(\mathrm{lit}^{21} 253-254^{\circ} \mathrm{C}\right) ; v_{\max }\left(\mathrm{KBr} / \mathrm{cm}^{-1}\right) 3467(\mathrm{~N}-\mathrm{H}), 2916,1624(\mathrm{CONH}) ;{ }^{1} \mathrm{H}$ NMR $(300$ MHz, DMSO-d ${ }_{6}$ ): $\delta=4.75$ (br s, $\left.2 \mathrm{H}, \mathrm{NH}\right), 6.54\left(\mathrm{td},{ }^{3} J=7.2 \mathrm{~Hz},{ }^{4} J=1.5 \mathrm{~Hz}, 1 \mathrm{H}, \mathrm{ArH}\right), 6.63-$ $6.78(\mathrm{~m}, 1 \mathrm{H}, \mathrm{ArH}), 6.69-6.75(\mathrm{~m}, 2 \mathrm{H}, \mathrm{ArH}), 6.84\left(\mathrm{td},{ }^{3} J=7.2 \mathrm{~Hz},{ }^{4} J=1.5 \mathrm{~Hz}, 1 \mathrm{H}, \mathrm{ArH}\right), 6.99$ $\left(\mathrm{dd},{ }^{3} J=7.7 \mathrm{~Hz},{ }^{4} J=1.5 \mathrm{~Hz}, 1 \mathrm{H} \mathrm{ArH}\right), 7.09-7.14(\mathrm{~m}, 2 \mathrm{H}, \mathrm{ArH} \times 2)$.

10,11-Dihydro-5-acetyl-dibenzo[b,e][1,4]diazepin-11-one ${ }^{22}$ (14). A solution of 10,11-dihydro$5 \mathrm{H}$-dibenzo[b,e][1,4]diazepin-11-one $\mathbf{1 3}(0.37 \mathrm{~g}, 1.76 \mathrm{mmol})$ was stirred at room temperature for 22 hours in acetic anhydride $(3.23 \mathrm{~g}, 31.68 \mathrm{mmol})$ and concentrated sulphuric acid $(0.21 \mathrm{~g}, 2.16$ mmol) was heated to reflux for 10 minutes. The solution was neutralized by slow addition of sodium bicarbonate and then extracted with dichloromethane $(3 \times 25 \mathrm{~mL})$. The combined extracts were dried over magnesium sulphate, filtered and the solvent evaporated under reduced pressure to give the product as a brown oil $0.32 \mathrm{~g}(73 \%) ; v_{\max }\left(\mathrm{KBr} / \mathrm{cm}^{-1}\right) 3386(\mathrm{~N}-\mathrm{H}), 3056$, $1698(\mathrm{CONH}), 1590 ;{ }^{1} \mathrm{H}$ NMR $\left(300 \mathrm{MHz}, \mathrm{DMSO}-\mathrm{d}_{6}\right): \delta=2.51\left(\mathrm{~s}, 3 \mathrm{H}, \mathrm{CH}_{3}\right), 7.11-7.29(\mathrm{~m}, 3 \mathrm{H}$, ArH x 3), 7.34-7.40 (m, 1H, ArH), 7.49-7.61 (m, 3H, ArH x 3), $7.75\left(\mathrm{~d},{ }^{3} J=7.7 \mathrm{~Hz}, 1 \mathrm{H}, \mathrm{ArH}\right)$. 


\section{Reaction of 2-acetamidobenzamide (1) with chlorotrimethylsilane}

Chlorotrimethylsilane $(3.16 \mathrm{~g}, 29.12 \mathrm{mmol})$ was added slowly to a refluxing solution of 2acetamidobenzamide 1 (1.00 g, $5.60 \mathrm{mmol})$ and triethylamine (2.95 g, 29.19 mmol) in chloroform $(10 \mathrm{~mL})$ under a nitrogen atmosphere. After 2 hours, the reaction mixture was allowed to cool to room temperature and the resulting precipitate collected by filtration. Silica gel chromatography using ethyl acetate - hexane (8:2) as eluant gave 2-methylquinazol-4-one 4 $(0.34 \mathrm{~g} ; 38 \%)$ and 2-acetamidobenzamide $(0.23 \mathrm{~g}, 23 \%)$, both as white crystalline solids; $v_{\max }$ and $\delta_{\mathrm{H}}$ as above.

\section{Reaction of 2-methyl-4H-benzo[d][1,3] oxazin-4-one (3) with tris(trimethylsilyl)amine}

To a stirring solution of 2-methyl-4H-benzo[d][1,3]oxazin-4-one $3(0.16 \mathrm{~g}, 1.00 \mathrm{mmol})$ in acetonitrile $(3.0 \mathrm{~mL})$ was added tris(trimethylsilyl)amine $(0.23 \mathrm{~g}, 1.00 \mathrm{mmol})$ under a nitrogen atmosphere. The resulting solution was stirred under a nitrogen atmosphere for 36 hours. The resulting precipitate was collected by filtration to give 2-methylquinazol-4-one 4 as a white crystalline solid, $0.53 \mathrm{~g}(33 \%)$; m.p. $237-238^{\circ} \mathrm{C}, v_{\max }$ and $\delta_{\mathrm{H}}$ as above. IR and PXRD were consistent with the anhydrous form.

2-Phenyl-4H-benzoxazin-4-one (16). To a stirred solution of anthranilic acid (8.88 g, 64.8 $\mathrm{mmol})$ in thf $(130 \mathrm{~mL})$ at $0^{\circ} \mathrm{C}$, sodium carbonate $(13.73 \mathrm{~g}, 129.6 \mathrm{mmol})$ was added followed by benzoyl chloride $(18.8 \mathrm{~mL}, 162 \mathrm{mmol})$. The resulting mixture was stirred for $10 \mathrm{~min}$ within this temperature range, warmed to room temperature and stirred for a further $24 \mathrm{~h}$. Water $(100 \mathrm{~mL})$ was added and the mixture was stirred for a further $10 \mathrm{~min}$ and then filtered. The precipitate was washed successively with water $(100 \mathrm{~mL})$ and $50 \%$ aqueous methanol $(100 \mathrm{~mL})$ and dried under vacuum to yield the desired compound as a pale yellow solid $13.53 \mathrm{~g} \mathrm{(94 \% );} \mathrm{m.p.}=122-124^{\circ} \mathrm{C}$ $\left[\mathrm{lit}^{26} 123^{\circ} \mathrm{C}\right] ; v_{\max }\left(\mathrm{KBr} / \mathrm{cm}^{-1}\right): 3029,1764,1599,1572,1474,1450,1314,1259,1214 ;{ }^{1} \mathrm{H} \mathrm{NMR}$ $\left(300 \mathrm{MHz}, \mathrm{CDCl}_{3}\right): \delta=7.36-7.53(\mathrm{~m}, 4 \mathrm{H}, \mathrm{ArH} x$ 4), $7.61(\mathrm{~d}, J=8.7 \mathrm{~Hz}, 1 \mathrm{H}, \mathrm{ArH}), 7.76(\mathrm{dt}, J=$ $8.4 \mathrm{~Hz}, J=0.75 \mathrm{~Hz}, 1 \mathrm{H}, \mathrm{ArH}), 8.15(\mathrm{dd}, J=8.8 \mathrm{~Hz}, 1.1 \mathrm{~Hz}, 1 \mathrm{H}, \mathrm{ArH}), 8.22(\mathrm{dd}, J=9.7 \mathrm{~Hz}, 1.3$ $\mathrm{Hz}, 2 \mathrm{H}, \mathrm{ArH}) \mathrm{ppm}$.

2-Benzoylamidobenzamide (17). An aqueous solution of ammonia (32\% $\left.\mathrm{NH}_{3}, 20 \mathrm{~mL}\right)$ was added to 2-phenyl-4H-benzoxazin-4-one 16 (1.12 g, $5.00 \mathrm{mmol})$. The resulting solution was stirred for $2 \mathrm{~h}$. The precipitate that formed was isolated by filtration and dried to afford the title compound as a white solid $0.59 \mathrm{~g}(49 \%)$; m.p. $=211-212^{\circ} \mathrm{C}\left[1 \mathrm{lit}^{27} 211-213{ }^{\circ} \mathrm{C}\right] ; v_{\max }\left(\mathrm{KBr} / \mathrm{cm}^{-1}\right)$ : 3390, 3187, 1764, 1659, 1619, 1591, 1525, 1494, 1397, 1323, 1311; ${ }^{1} \mathrm{H}$ NMR (300 MHz, DMSO-d $_{6}$ ): $\delta=7.13(\mathrm{dt}, J=8.3 \mathrm{~Hz}, 0.2 \mathrm{~Hz}, 1 \mathrm{H}, \mathrm{ArH}), 7.51-7.54(\mathrm{~m}, 4 \mathrm{H}, \mathrm{ArH} \times 4), 7.75$ (br s, $1 \mathrm{H}, \mathrm{NH}), 7.78-8.00(\mathrm{~m}, 3 \mathrm{H}, \mathrm{ArH} \times 3), 8.46$ (br s, $1 \mathrm{H}, \mathrm{NH}), 8.69$ (d, $J=9.8 \mathrm{~Hz}, 1 \mathrm{H}, \mathrm{ArH}) .12 .24$ (bs, 1H, ArNH) ppm.

2-Phthalimidobenzoic acid (18). A solution of anthranilic acid ( $0.80 \mathrm{~g}, 5.80 \mathrm{mmol})$ and phthalic anhydride $(0.86 \mathrm{~g}, 5.80 \mathrm{mmol})$ in acetonitrile was heated to reflux for 2 hours. After cooling to room temperature, the precipitated solid was collected by filtration to give a while crystalline solid (1.39 g, 90\%); m.p. $210^{\circ} \mathrm{C}\left(\mathrm{lit}^{28} 212^{\circ} \mathrm{C}\right) \cdot v_{\max }\left(\mathrm{KBr} / \mathrm{cm}^{-1}\right): 3030(\mathrm{OH}), 1715(\mathrm{C}=\mathrm{O}) .{ }^{1} \mathrm{H}$ NMR (300 MHz, DMSO-d $\left.)_{6}\right): \delta=7.23\left(\mathrm{dt},{ }^{3} J=8.0 \mathrm{~Hz},{ }^{4} J=1.5 \mathrm{~Hz}, 1 \mathrm{H}, \mathrm{ArH}\right), 7.61-7.73(\mathrm{~m}, 4 \mathrm{H}$, 
ArH x 4), $7.99\left(\mathrm{~d},{ }^{3} J 7.5 \mathrm{~Hz}, 1 \mathrm{H}, \mathrm{ArH}\right), 8.06\left(\mathrm{dd},{ }^{3} J 8.0 \mathrm{~Hz},{ }^{4} J=1.5 \mathrm{~Hz}, 1 \mathrm{H}, \mathrm{ArH}\right), 8.65\left(\mathrm{~d},{ }^{3} J=\right.$ $7.5 \mathrm{~Hz}, 1 \mathrm{H}, \mathrm{ArH}), 11.58$ (br s, 1H, OH) ppm.

2-Phthalimidobenamide (19). A solution of anthranilamide (0.50 g, $3.67 \mathrm{mmol})$ and phthalic anhydride $(0.54 \mathrm{~g}, 3.67 \mathrm{mmol})$ in acetonitrile $(30 \mathrm{~mL})$ was heated to reflux for 30 minutes. After cooling to room temperature, the precipitated solid was collected by filtration to give the products as a white crystalline solid $\left(0.56\right.$ g, 57\%), m.p. $234-237^{\circ} \mathrm{C}\left(\mathrm{lit}^{29} 239^{\circ} \mathrm{C}\right) . v_{\max }(\mathrm{KBr} /$ $\left.\mathrm{cm}^{-1}\right): 3430,3245(\mathrm{NH}), 1766,1718$ and $1667(\mathrm{C}=\mathrm{O}) .{ }^{1} \mathrm{H}$ NMR $\left(300 \mathrm{MHz}, \mathrm{DMSO}-\mathrm{d}_{6}\right): \delta=7.19$ $\left(\mathrm{dt},{ }^{3} J 8.1 \mathrm{~Hz},{ }^{4} J=1.0 \mathrm{~Hz}, 1 \mathrm{H}, \mathrm{ArH}\right), 7.55-7.69$ (m, 4H, ArH), 7.84-7.89 (m, 2H, ArH), 8.62 (d, $\left.{ }^{3} J=8.1 \mathrm{~Hz}, \mathrm{ArH}\right), 12.21-12.26$ (br s, $2 \mathrm{H}, \mathrm{NH}_{2}$ ).

\section{Acknowledgements}

The authors are grateful for financial support from GlaxoSmithKline (Ireland) and Pfizer (Ireland), for the assistance of Alan Kennedy with one of the experiments, and to Prof. M. A. Morris and Dr. J. D. Holmes for access to PXRD instrumentation.

\section{References}

1. Bernstein, J. Polymorphism in Molecular Crystals, Clarendon Press, Oxford, 2002. (b) Davey, R. J. Chem. Commun. 2003, 1463.

2. Rodríguez-Spong, B.; Price, C. P.; Jayasankar, A.; Matzger, A. J.; Rodríguez-Hornedo, N. Adv. Drug Del. Rev. 2004, 56, 241.

3. Erk, P. Current Opinions in Solid State and Material Sci. 2001, 5, 155.

4. N. Li, N.; Shanks, R. A.; Murphy, D. M. J. Cryst. Growth 2001, 224, 128.

5. Errede, L. A.; Etter, M. C.; Williams, R. C.; Darnauer, S. M. J. Chem. Soc., Perkin Trans. 2 1980, 233.

6. D. Buttar, D.; Charlton, M. H.; Docherty, R. Starbuck, J. J. Chem. Soc., Perkin Trans. 2 1998, 763.

7. Weddige, A. J. Prakt. Chem. 1887, 36, 141.

8. Anschutz, R.; Schmidt, O.; Griffenberg, A. Ber. Dtsch. Chem. Ges. 1901, 35, 3483.

9. Errede, L. A.; Martinucci, P. D.; McBrady, J. J. J. Org. Chem. 1980, 45, 3009.

10. Barnett, S. A.; Tocher, D. A.; Vickers, M. CrystEngComm. 2006, 8, 313.

11. Etter, M. C. J. Chem. Soc., Perkin Trans 2 1983, 115.

12. (a)Almarsson, Ö.; Zaworotko, M. J. Chem. Commun. 2004, 1889; Remenar, J. F.; Morissette, S. L.; Peterson, M. L.; Moulton, B.; MacPhee, J. M.; Guzman, H. R.; Almarsson, Ö. J. Am. Chem. Soc. 2003, 125, 8456. (b) Oswald, I. D. H.; Motherwell, W. D. S.; Parsons, S.; Pidcock, E.; Pulham, C. R. Crystallography Reviews 2004, 10, 57. 
13. Edwards, A. D.; Shekunov, B. Y.; Kordikowski, A.; Forbes, R. T.; York, P. J. Pharm. Sci. 2001, 90, 1115.

14. McCausland, L. J.; Cains, P. W.; Martin, P. D. Chem. Eng. Prog. 2001, 56.

15. Zaccaro, J.; Matic, J.; Myerson, A. S.; Garetz, B. A. Crystal Growth \& Design 2001, 1, 5.

16. Chyall, L.; Tower, J. M.; Coates, D. A.; Houston, T. L.; Childs, S. L. Crystal Growth \& Design 2002, 2, 505.

17. (a)Weissbuch, I.; Berkovic, G.; Leiserowitz, L.; Lahav, M. J. Am. Chem. Soc. 1990, 112, 5874. (b) Weissbuch, I.; Frolow, F.; Addadi, L.; Leiserowitz, L.; Lahav, M. J. Am. Chem. Soc. 1990, 110, 561. (c) Bonafede, S. J.; Ward, M. D. J. Am. Chem. Soc. 1995, 117, 7854.

18. Weissbuch, I.; Leisorowitz, L.; Lahav, M. Adv. Mater. 1994, 6, 952. (b) Staab, E.; Addadi, L.; Leiserowitz, L. Adv. Mater. 1990, 2, 40.

19. Davey, R. J.; Blagden, N.; Potts, G. D.; Docherty, R. J. Am. Chem. Soc. 1997, 119, 1767.

20. Dunitz, J. D.; Bernstein, J. Acc. Chem. Res. 1995, 28, 193.

21. MM2 in Chem3D Pro version 5.0, CambridgeSoft Corp.

22. Hanze, A. R.; Strube, R. E.; Greig, M. E. J. Med. Chem. 1963, 6, 767.

23. (a) M. Jetten, M.; Peters, C. A. M.; van Nispen, J. W. F. N.; Ottenheijm, H. C. J. Tetrahedron Lett. 1991, 32, 6025. (b) Moynihan, H. A.; Yu, W. Tetrahedron Lett. 1998, 39, 3349.

24. Errede, L. A. J. Org. Chem. 1976, 41, 1763.

25. Tomisek, A. J.; Christensen, B. E. J. Am. Chem. Soc. 1948, 70, 2423.

26. Davis, M.; Pogany, S. P. J. Heterocycl. Chem. 1977, 14, 267.

27. Trepanier, D. L.; Sunder, S. J. Heterocyclic Chem. 1975, 12, 321.

28. Wiklund, P.; Romero, I.; Bergman, J. Org. Biomol. Chem. 2003, 1, 3396.

29. Kurihara, M. J. Org. Chem., 1969, 34, 2123. 